\title{
PENGARUH IMPLEMENTASI ASESMEN PROJEK TERHADAP KARAKTER DAN LITERASI SAINS SISWA KELAS IV SD GUGUS 2 KECAMATAN BULELENG
}

\section{INFO ARTIKEL}

Riwayat Artikel:

Diterima: 08-Januari-2021

Disetujui: 30-Maret-2021

\section{Kata Kunci: \\ Literasi Sains, Karakter, Asesmen Projek}

\author{
Ahmad Baihaqi Rifqi \\ UPTD SPF SD Negeri Solor 5 \\ Alamat: Kecamatan Cermee Kabupaten Bondowoso \\ e-mail: ahmadbaihaqirifqi@gmail.com
}

\begin{abstract}
ABSTRAK
Abstrak: Penelitian ini bertujuan untuk mengetahui pengaruh implementasi asesmen projek terhadap karakter dan literasi sains siswa. Populasi penelitian ini adalah seluruh kelas IV SD di Gugus II Kecamatan Buleleng Kabupaten Buleleng yang berjumlah 114 siswa dan sampel berjumlah 47 siswa. Penetapan sampel dilakukan dengan teknik simple random sampling. Penelitian ini merupakan quasi eksperimen dengan rancangan Single Factor Independent Group Design. Teknik pengumpulan data menggunakan kuesioner untuk karakter dan tes untuk literasi sains. Data dianalisis dengan menggunakan multi analisis varians. Hasil penelitian menunjukkan uji hipotesis pertama nilai $\mathrm{F}=$ 15,813 dengan signifikansi $0.000<0.05$ yang artinya $\mathrm{H}_{\mathrm{o}}$ ditolak dan $\mathrm{H}_{1}$ diterima, terdapat perbedaan karakter siswa yang mengikuti pembelajaran dengan implementasi asesmen projek dengan siswa yang mengikuti pembelajaran dengan implementasi asesmen konvensional. Hasil uji hipotesis kedua menunjukkan bahwa $\mathrm{F}=20,471$ dengan $0,000<0,05$ yang artinya $\mathrm{H}_{\mathrm{o}}$ ditolak dan $\mathrm{H}_{1}$ diterima, terdapat perbedaan yang signifikan antara literasi sains siswa yang mengikuti pembelajaran dengan implementasi asesmen projek dengan siswa yang mengikuti pembelajaran dengan implementasi asesmen konvensional. Uji hipotesis ketiga menunjukan bahwa $F=18,868$ dengan $0,000<0,05$ yang artinya $\mathrm{H}_{0}$ ditolak dan $\mathrm{H}_{1}$ diterima, terdapat perbedaan karakter dan literasi sains siswa secara simultan antara siswa yang mengikuti pembelajaran dengan implementasi asesmen projek dengan siswa yang mengikuti pembelajaran dengan implementasi asesmen konvensional.
\end{abstract}

\begin{abstract}
This study aims to determine the effect of the implementation of the project assessment on students' character and scientific literacy. The population of this study were all fourth grade elementary school students in Cluster II, Buleleng District, Buleleng Regency, totaling 114 students and a sample of 47 students. The samples were determined using simple random sampling technique. This research is a quasi-experimental design with a single factor independent group design. The data collection technique used a questionnaire for character and tests for scientific literacy. Data were analyzed using multi analysis of variance. The results showed that the first hypothesis test, the value of $F=15.813$ with a significance of $0.000<0.05$, which means that Ho is rejected and H1 is accepted, there are differences in the character between students who took learning with the implementation of project assessments with students who took learning with the implementation of conventional assessment. The results of the second hypothesis test showed that $F=20.471$ with $0.000<0.05$, which means that Ho is rejected and $\mathrm{Hl}$ is accepted, there was a significant difference between the scientific literacy of students who took part in learning with the implementation of project assessments and students who took learning with the implementation of conventional assessment. The third hypothesis test showed that $F=18.868$ with $0.000<0.05$, which means that Ho is rejected and HI is accepted, there are differences in the character and scientific literacy of students simultaneously between students who take learning by implementing project assessment with students who take learning with the implementation of conventional assessment.
\end{abstract}

This is an open access article under the $\mathrm{BY}-\mathrm{NC}$-ND license

\section{A. LATAR BELAKANG}

Cita-cita bangsa Indonesia untuk melahirkan generasi cemerlang yang mampu bersaing di era global. Citacita tersebut adalah melahirkan generasi emas 2045. Generasi emas adalah generasi yang diharapkan menjadi perintis perubahan dalam membentuk kehidupan dan peradaban bangsa yang lebih baik. Untuk membangun generasi emas 2045 yang di cita-citakan Indonesia, pendidikan harus membekali siswa dengan keterampilan 
abad 21. Keterampilan abad 21 yang dimaksud adalah 1) lima nilai utama penguatan pendidikan karakter yaitu religius, nasionalis, mandiri, gotong royong, dan integritas, 2) literasi dasar meliputi literasi baca tulis, literasi berhitung, literasi sains, literasi teknologi informatika dan komunikasi, literasi finansial, dan literasi budaya dan kewarganegaraan, 3) kompetensi untuk memecahkan masalah yaitu berpikir kritis, kreativitas, komunikasi, dan kolaborasi. Kurikulum 2013 diharapkan dapat diimplementasikan pembelajaran abad 21. Hal ini untuk menyikapi tuntutan zaman yang semakin kompetitif. Salah satu keterampilan abad 21 untuk membangun generasi emas 2045 adalah pendidikan karakter.

Pendidikan karakter merupakan melahirkan lingkungan sekolah yang dapat membantu peserta didik dalam perkembangan etika, tanggung jawab melalui model, dan pengajaran karakter yang baik melalui nilai-nilai universal (Maunah, 2015). Pendidikan karakter merupakan suatu proses kegiatan yang mengarah pada peningkatan kualitas pendidikan dan pengembangan budi pekerti dan nilai-nilai moral yang selalu mengajarkan, membimbing, dan membina setiap peserta didik agar memiliki kompetensi intelektual, karakter, dan keterampilan. Pendapat di atas sudah jelas bahwa pendidikan karakter adalah pendekatan yang dilakukan secara langsung untuk pendidikan moral dengan memberi pelajaran kepada peserta didik tentang pengetahuan moral dasar untuk mencegah mereka melakukan perilaku tidak bermoral atau membahayakan bagi diri sendiri maupun orang lain.

Pendidikan karakter bertujuan untuk meningkatkan mutu pendidikan yang mengarah pada pencapaian pembentukan karakter atau akhlak mulia peserta didik secara utuh, terpadu, seimbang, dan sesuai dengan standar kompetensi kelulusan. Melalui upaya pembentukan karakter pada peserta didik, maka akan membentuk peserta didik yang cerdas, tetapi tidak hanya cerdas dalam bidang pembelajaran saja, namun juga harus mempunyai nilai-nilai moral yang baik, seperti bersikap sopan, patuh terhadap aturan, dan bersikap jujur.

Karakter selalu ditekankan di setiap perubahan kurikulum, namun hasilnya masih memprihatinkan. Hasil Survei yang dilansir dari Selamatkan Generasi Emas Indonesia (Jazari, 2018) menyebutkan bahwa 93 dari 100 pelajar sudah mengakses situs pornografi, 63 dari 100 remaja melakukan hubungan sek di luar nikah dan 21 dari 100 remaja melakukan aborsi. Fakta ini menunjukkan bahwa kita sedang mengalami krisis moral yang jika tidak segera disadari dan dilakukan perbaikan maka dipastikan generasi emas yang kita harapkan hanya akan menjadi impian semata, ibarat pepatah yang mengatakan layu sebelum berkembang. Sudah banyak strategi, cara dan kebijakan yang dilakukan dalam pelaksanaan pendidikan karakter, namun hasilnya belum menggembirakan. Putri (2018) mengatakan bahwa cara terbaik untuk meningkatkan kualitas karakter, kompetensi dan kesejahteraan hidup seseorang, adalah dengan menanamkan budaya literasi (membaca-berpikir-menulisberkreasi). Literasi diharapkan mampu menjadi sarana pembentuk pola pikir, sikap, dan perilaku anak bangsa. Literasi merupakan salah satu keterampilan abad 21 yang harus dibekali kepada siswa untuk membangun generasi emas 2045. Salah satu Literasi yang dituntut di keterampilan abad 21 adalah literasi sains.

Studi Programme for International Student Assessment (PISA) (dalam OECD, 2016) mendefinisikan literasi sains sebagai kemampuan menggunakan pengetahuan sains, mengidentifikasi pertanyaan, dan menarik kesimpulan berdasarkan bukti-bukti, dalam rangka memahami serta membuat keputusan berkenaan dengan alam dan perubahan yang dilakukan terhadap alam melalui aktivitas manusia. Literasi sains (scientific literacy) kini menjadi tuntutan untuk dikuasai oleh setiap individu baik dalam kehidupan sehari-hari maupun dalam dunia pekerjaan. Individu yang melek sains dapat menggunakan informasi ilmiah yang dimilikinya untuk mengatasi masalah dalam kehidupan sehari-hari serta menghasilkan produk-produk ilmiah yang bermanfaat. Literasi sains adalah kemampuan seseorang untuk memahami sains, mengkomunikasikan sains, serta menerapkan pengetahuan sains untuk memecahkan masalah sehingga memiliki sikap dan kepekaan yang tinggi terhadap diri dan lingkungannya dalam mengambil keputusan berdasarkan pertimbangan sains (Toharudin dalam Wulandari, 2016). Konsep literasi sains mengharapkan siswa untuk memiliki rasa kepedulian yang tinggi terhadap diri dan lingkungannya dalam menghadapi permasalahan kehidupan sehari-hari dan mengambil keputusan berdasarkan pengetahuan sains yang telah dipahaminya.

Literasi sains sangat penting dimiliki oleh siswa. Siswa yang memiliki literasi sains akan dapat menerapkan pengetahuan mereka untuk memecahkan permasalahan dalam situasi kehidupan sehari-hari baik dalam lingkup pribadi, sosial atau pun global. Untuk meningkatkan literasi sains dalam pembelajaran sains yaitu dengan menghubungkan suatu konsep sains dengan topik yang sedang berkembang dan menarik dalam kehidupan nyata. Peserta didik diharapkan menjadi aktif dalam pembelajaran dengan menggunakan topik yang baru dan menarik dalam kehidupan nyata.

Pendidikan literasi sains di Indonesia merupakan cita-cita untuk melahirkan generasi emas 204. Namun pada kenyataannya menurut OECD (2016) mengumumkan hasil dari Studi Literasi yang diadakan oleh PISA 2015 menunjukkan bahwa kemampuan Literasi Sains Indonesia pada 2015 terburuk kesebelas dari 72 negara yang diteliti di dunia. Indonesia menempati urutan ke 62 dari 72 negara dengan skor 403 pada bidang literasi sains. Secara gambaran umum literasi sains peserta didik di Indonesia masih berada di bawah rata-rata 
dibandingkan dengan negara- negara lain. Hasil tersebut menunjukkan bahwa siswa Indonesia untuk melek terhadap sains dan teknologi masih sangat rendah serta pendidikan literasi sains di Indonesia cukup memprihatinkan. Berdasarkan hasil studi literasi sains yang diadakan oleh PISA, tergambar bahwa kemampuan siswa Indonesia dalam bersaing di tingkat Internasional masih harus lebih ditingkatkan. Dalam beberapa periode tahun terakhir ini Indonesia menempati peringkat bawah di antara negara-negara peserta studi literasi lainnya.

Sesuai data yang ditunjukkan dalam Republika (2018) menunjukkan jumlah waktu yang digunakan anak Indonesia dalam menonton televisi adalah 300 menit per hari. Jumlah ini terlalu besar dibanding anak-anak di Australia yang hanya 150 menit per hari dan di Amerika yang hanya 100 menit per hari. Sementara di Kanada 60 menit per hari. Sungguh miris jika kita melihat pada fakta yang terjadi di Indonesia. Kurangnya minat literasi sains pada anak-anak di Indonesia adalah suatu masalah yang harus diatasi. Ada beberapa faktor yang mempengaruhi rendahnya literasi sains siswa. Penyebab rendahnya literasi sains yaitu adanya kecenderungan bahwa proses pembelajaran yang tidak mendukung peserta didik dalam mengembangkan kemampuan literasi sains dan siswa belum terbiasa mengerjakan soal menggunakan wacana serta menurut siswa tes literasi lebih sulit dibandingkan dengan soal ujian yang biasa diberikan guru (Astuti, 2017). Karena pentingnya karakter dan literasi sains maka pendidikan harus sungguh-sungguh mengembangkan kedua hal ini. Namun pada kenyataannya menurut penelitian Subanji (2017) pada saat ini, hampir setiap hari siswa dihadapkan pada informasi-informasi yang "tidak jarang" menunjukkan karakter "tidak baik", seperti yang ditayangkan di sinetron, film, pertunjukan langsung, WhatsApp, Instagram, dan sebagainya. Demikian pula berbagai perilaku negatif sering disaksikan oleh siswa melalui berbagai media, seperti adanya tawuran pelajar, tawuran suporter, tindakan anarkis, keterlibatan dalam narkoba, dan sebagainya. Serta Menurut OECD (2016) dalam studi PISA tahun 2015 mengumumkan bahwa pada bidang literasi sains Indonesia menduduki peringkat 62 dari 72 negara dengan skor 403. Hal tersebut membuktikan bahwa karakter dan literasi sains di Indonesia masih rendah. Dengan rendahnya kedua hal tersebut, apa inovasi pendidikan atau pembelajaran yang perlu dilakukan.

Asesmen sangat berperan dalam menentukan arah pembelajaran dan kualitas pendidikan serta dalam menentukan arah pembelajaran dan kualitas pendidikan tersebut dibutuhkan asesmen yang dapat memperbaiki proses pembelajaran (Pantiwati, 2013). Pendapat yang selaras juga dinyatakan oleh Agustini (2014) bahwa kualitas pembelajaran yang baik diperlukan sistem penilaian yang baik pula. Jadi, kualitas pembelajaran tergantung pada kualitas asesmennya. Menurut Nitko dalam Marhaeni (2017) Asesmen merupakan suatu proses mendapatkan data yang digunakan untuk mengambil keputusan mengenai pembelajar, program pendidikan dan kebijakan pendidikan. Salah satu asesmen dalam kurikulum 2013 adalah asesmen autentik. Asesmen autentik (authentic assesment) adalah suatu proses pengumpulan, pelaporan dan penggunaan informasi tentang hasil belajar siswa dengan menerapkan prinsip-prinsip penilaian, pelaksanaan berkelanjutan, bukti-bukti autentik, akurat, dan konsisten sebagai akuntabilitas publik (Alfian dkk, 2015). Penilaian autentik dikembangkan karena penilaian yang sering digunakan saat ini kurang menggambarkan kemampuan siswa yang sebenarnya. Salah satu jenis asesmen autentik di SD dalam kurikulum 2013 adalah asesmen projek. Menurut Kunandar (2015) Penilaian projek merupakan kegiatan penilaian terhadap suatu tugas yang meliputi: pengumpulan, pengorganisasian, pengevaluasian, dan penyajian data yang harus diselesaikan peserta didik (individu/kelompok) dalam waktu atau periode tertentu. Asesmen projek merupakan salah satu bentuk penilaian autentik dengan memberikan tugas pada siswa secara individu maupun berkelompok (Muchtar, 2010).

Penilaian projek merupakan penilaian yang berpusat pada proses, relatif berjangka waktu, berfokus pada masalah, unit pembelajaran bermakna dengan memadukan konsep-konsep dari sejumlah komponen baik itu pengetahuan, disiplin ilmu atau lapangan. Pada pembelajaran berbasis projek kegiatan pembelajarannya berlangsung secara kolaboratif dalam kelompok yang heterogen. Mengingat hakikat kerja projek adalah kolaboratif, maka pengembangan keterampilan belajar berlangsung di antara siswa. Pada pembelajaran berbasis projek kekuatan individu dan cara belajar yang diacu dapat memperkuat kerja tim sebagai suatu keseluruhan. Penilaian projek merupakan salah satu jenis penilaian yang mengakomodasi perbedaan gaya belajar siswa dan digunakan untuk menilai proses di samping produk hasil projek sebagai sumber penilaian. Penilaian projek menekankan pada kemampuan merencanakan, mengorganisasikan investigasi, dan kerja sama dalam tim. Penilaian yang menuntut siswa untuk belajar bersama dalam sebuah tim akan memunculkan kekuatan dan kemampuan masing-masing siswa untuk menunjukkan performanya selama proses pembelajaran.

Sepintas ketika dilihat asesmen projek ini sebenarnya kuat untuk bisa meningkatkan karakter karena di dalam asesmen projek siswa dituntut melakukan kerja kelompok yang mengharuskan siswa untuk meningkatkan karakter gotong royong meliputi kerja sama dan solidaritas serta menghargai pendapat dari teman. Dan juga asesmen projek ini sebenarnya juga kuat untuk meningkatkan literasi sains siswa karena projek-projek yang berorientasi sains akan membiasakan siswa merencanakan, melaksanakan dan melaporkan sehingga mereka berpikir sistematis. Tampaknya belum banyak guru menggunakan asesmen projek untuk meningkatkan karakter dan literasi sains. Oleh karena itu perlu penelitian tentang hal tersebut. 


\section{B. METODE PENELITIAN}

Penelitian ini merupakan penelitian eksperimen semu (quasi eksperimen) terhadap siswa dalam suatu kelas. Rancangan eksperimen yang digunakan adalah rancangan Eksperiment Single Factor Independent Group Design. Dalam rancangan ini subyek yang diambil dari populasi dikelompokkan menjadi dua kelompok yang masing-masing dipilih secara acak. Kelompok pertama merupakan kelompok eksperimen dan kelompok kedua adalah kelompok kontrol. Untuk kelompok eksperimen dikenakan implementasi asesmen projek dan kelompok kontrol diberikan implementasi asesmen konvensional dalam jangka waktu tertentu, kemudian kedua kelompok dikenakan pengukuran yang sama. Perbedaan hasil pengukuran yang timbul di anggap sumber dari variabel pengukuran.

Tabel 1. Rancangan eksperimen

\begin{tabular}{|l|l|l|l|}
\hline A1 & A2 \\
\hline Y1 & Y2 & Y1 & Y2 \\
\hline
\end{tabular}

Keterangan:

$\mathrm{A} 1$ = Kelompok eksperimen

A2 $=$ Kelompok kontrol

$\mathrm{Y} 1=$ Karakter

$\mathrm{Y} 2$ = Literasi Sains

Penelitian ini dilaksanakan pada semester 1 tahun ajaran 2018/2019. Populasi penelitian ini adalah seluruh siswa kelas IV SD pada Gugus 2 Buleleng yang berjumlah 115 siswa yang terdiri dari 5 kelas yang tersebar dalam tujuh SD yaitu SDN 1 Penarukan, SDN 2 Penarukan, SDN 3 Penarukan, SDN 4 Penarukan, dan SDN 5 Penarukan. Pengambilan sampel dalam penelitian ini dilakukan dengan teknik sampel random sampling diperoleh sampel sebanyak 48 siswa, dengan kelas IV pada SDN 1 Penarukan sebagai kelas eksperimen yang berjumlah 25 siswa dan kelas IV pada SDN 5 Penarukan sebagai kelas kontrol yang berjumlah 23 siswa.

Pengumpulan data dalam penelitian ini menggunakan kuesioner karakter dan tes literasi sains. Uji persyaratan analisis dalam penelitian ini adalah: (1) uji normalitas sebaran data, (2) uji homogenitas varians, dan (3) uji korelasi antar variabel terikat. Analisis data yang digunakan adalah analisis MANOVA.

\section{HASIL DAN PEMBAHASAN}

\begin{tabular}{|l|c|c|c|c|}
\hline \multirow{4}{*}{ Variabel Statistik } & $\begin{array}{c}\text { Kelompok } \\
\text { Eksperimen } \\
\text { (A1) }\end{array}$ & $\begin{array}{c}\text { Kelompok } \\
\text { Kontrol } \\
\text { (A2) }\end{array}$ & \multicolumn{2}{|c|}{} \\
\cline { 2 - 3 } & Karakter (Y1) & $\begin{array}{c}\text { Literasi Sains } \\
\text { (Y2) }\end{array}$ & $\begin{array}{c}\text { Karakter } \\
\text { (Y1) }\end{array}$ & $\begin{array}{c}\text { Literasi Sains } \\
\text { (Y2) }\end{array}$ \\
\hline $\mathrm{N}$ & 25 & 25 & 23 & 23 \\
\hline Rata-rata & 65,14 & 69,80 & 58,61 & 59,57 \\
\hline Median & 62,86 & 70 & 59,43 & 60 \\
\hline Varians & 39,05 & 48,92 & 25,02 & 74,80 \\
\hline Std. Deviasi & 6,25 & 6,99 & 5,00 & 8,65 \\
\hline Nilai Minimum & 56,57 & 55 & 50,86 & 40 \\
\hline Nilai Maximum & 74,86 & 80 & 71,43 & 75 \\
\hline Rentangan & 18,29 & 25 & 20,57 & 35 \\
\hline \multicolumn{1}{|c|}{ Total } & 1628,57 & 1745 & 1348 & 1370 \\
\hline
\end{tabular}

Uji normalitas sebaran data dilakukan dengan uji Kolmogorov-Smirnov. Berdasarkan hasil analisis terlihat nilai Sig. dari semua kelompok data yang diperoleh dengan sig. > 0,05 maka sebaran data berdistribusi normal. Uji homogenitas varians dilakukan dengan menggunakan uji Barlett. Berdasarkan hasil analisis terlihat nilai sig. $>0,05$ dan $\mathrm{x}^{2}$ hitung $(6,779)<\mathrm{x}^{2}$ tabel $(7,815)$. Dengan demikian data penelitian tersebut homogen.

Uji korelasi dilakukan menggunakan korelasi Product Moment. Berdasarkan hasil analisis menunjukkan bahwa $\mathrm{r}_{\mathrm{xy}}$ yang bernilai $0,238<0,8$ dan memiliki nilai signifikan sebesar 0,104 atau sig. $>0,05$. Dengan demikian data penelitian tersebut menunjukkan bahwa hubungan atau korelasi antar variabel terikat tidak signifikan atau tidak ada korelasi antar variable terikat. Berarti matriks varian/covarian dari variabel dependen sama, sehingga analisis MANOVA dapat dilanjutkan.

Pengujian hipotesis pertama menggunakan analisis varian satu jalur (ANAVA A) melalui statistik varians ( $F$ antar) diperoleh nilai $F_{\text {hitung }}=15,813$ sedangkan $F_{\text {tabel }}=4.06$. Ini berarti $F_{\text {hitung }}>F_{\text {tabel }}$ dan sig. $=<0,001$. Ini 
berarti sig. $<0,05$. Jadi hipotesis nol yang menyatakan bahwa tidak terdapat perbedaan karakter siswa yang mengikuti pembelajaran dengan implementasi asesmen projek dengan siswa yang mengikuti pembelajaran dengan implementasi asesmen konvensional, ditolak. Dengan demikian, dapat ditarik kesimpulan bahwa terdapat perbedaan karakter siswa yang mengikuti pembelajaran dengan implementasi asesmen projek dengan siswa yang mengikuti pembelajaran dengan implementasi asesmen konvensional.

Hasil temuan perbedaan pencapaian karakter tersebut dapat dijelaskan penyebabnya dari sudut pandang secara teoritik antara pembelajaran dengan implementasi asesmen projek dan asesmen konvensional dimana keduanya memiliki karakteristik yang berbeda dilihat dari hakikat pengertiannya asesmen projek adalah kegiatan penilaian terhadap suatu tugas yang meliputi: pengumpulan, pengorganisasian, pengevaluasian, dan penyajian data yang harus diselesaikan peserta didik (individu/kelompok) dalam waktu atau periode tertentu (Kunandar, 2013). Pada Langkah-langkah pembelajaran dengan implementasi asesmen projek yaitu pertama persiapan: persiapan diawali dengan penjelasan guru tentang materi yang dipelajari yang diikuti dengan instruksi tugas projek yang dilengkapi dengan persyaratan tertentu, termasuk ketentuan waktu, kedua pelaksanaan: dalam proses pelaksanaan/penyelesaian projek guru berperan untuk memonitor progres dan sekaligus memberi masukan demi kesempurnaan produk dan keluasan belajar siswa, ketiga penilaian: Penilaian proses dan hasil projek yaitu meninjau proses pelaksanaan projek dan menilai produk yang dihasilkan untuk mengetahui ketercapaian tujuan projek (Marhaeni, 2017).

Hal tersebut sangatlah berbeda dengan asesmen konvensional, dimana asesmen konvensional adalah sistem penilaian yang biasa digunakan oleh guru dalam proses pembelajaran selama ini (Solikhin, 2014). Kemudian dilihat dari ciri-ciri asesmen konvensional yaitu 1) Penilaian Normatif, 2) Terfokus pada isi materi, 3) Hasil penilaian berupa nilai-nilai, 4) Berbasis waktu, 5) Kecepatan belajar kelompok, 6) Penilaian ditekankan pada pengetahuan, 7) Pendekatan pembelajaran yang sempit dan berorientasi pada text book, dan 8) Feedback penilaian terlambat/tidak ada. Berdasarkan paparan diatas terlihat jelas perbedaannya bahwa implementasi asesmen projek perlu diterapkan dalam suatu proses pembelajaran karena melibatkan keaktifan siswa dalam kegiatan proses dan projek pembelajaran sehingga mampu memperbaiki cara bersikap siswa sejalan dengan hal tersebut karakter siswa pun akan terbangun dengan sendirinya dan berkembang dalam proses pembelajaran.

Penelitian lain yang senada dengan hasil penelitian ini adalah penelitian yang dilakukan oleh Akbar dkk, (2016) Dampak Asesmen Portofolio terhadap Pemahaman Konsep dan Sikap Siswa Sekolah Menengah Pertama pada Materi Gaya dan Gerak. Dalam hasil penelitian tersebut menunjukkan bahwa pembelajaran dengan asesmen berpengaruh tinggi terhadap peningkatan sikap atau karakter siswa dalam pembelajaran IPA.

Pengujian hipotesis kedua menggunakan analisis varian satu jalur (ANAVA A) melalui statistik varians (F antar) diperoleh nilai $F_{\text {hitung }}=20,471$ sedangkan $F_{\text {tabel }}=4.06$. Ini berarti $F_{\text {hitung }}>F_{\text {tabel }}$ dan sig. $=\langle 0,001$. Ini berarti sig. $<0,05$. Jadi hipotesis nol yang menyatakan bahwa tidak terdapat perbedaan literasi sains siswa yang mengikuti pembelajaran dengan implementasi asesmen projek dengan siswa yang mengikuti pembelajaran dengan implementasi asesmen konvensional, ditolak. Dengan demikian, dapat ditarik kesimpulan bahwa terdapat perbedaan literasi sains siswa yang mengikuti pembelajaran dengan implementasi asesmen projek dengan siswa yang mengikuti pembelajaran dengan implementasi asesmen konvensional.

Hasil temuan perbedaan pencapaian literasi sains siswa dapat dijelaskan dari beberapa tinjauan antara asesmen projek dengan asesmen konvensional dimana keduanya memiliki perbedaan dalam segi landasan teoritik dan empiris. Dalam tinjauan pertama berdasarkan landasan teoritik penilaian kegiatan yang menggunakan model kegiatan projek pasti menggunakan asesmen projek. Kegiatan projek adalah cara yang amat baik untuk melibatkan siswa dalam pemecahan masalah karena bersifat sangat ilmiah apalagi ditunjang dengan kegiatan yang berhubungan dengan dunia nyata (Pantiwati, 2008). Projek dapat melibatkan siswa secara aktif dan menemukan situasi baru yang dapat mendorong siswa menemukan suatu masalah sehingga dapat menuntun mereka merumuskan hipotesis yang membutuhkan penyelidikan lebih lanjut. Untuk sekolah tingkat dasar melalui projek juga menyediakan peluang bagi siswa untuk mengeksplorasi ide-ide ilmiah dengan menggunakan materi fisik atau teknologi baru. Siswa dapat diarahkan untuk melakukan investigasi permasalahan yang ada di sekitar kehidupan siswa baik lingkungan sekolah maupun tempat tinggal siswa.

Tinjauan kedua berdasarkan sudut pandang operasional empiris pada pembelajaran dengan implementasi asesmen projek dalam pembelajarannya siswa dibelajarkan untuk memecahkan masalah yang berkaitan dengan kehidupan nyata menggunakan pengetahuan sains yang dimilikinya.

Hal berbeda dengan pembelajaran asesmen konvensional dalam proses pembelajaran sebagian besar menilai siswa pada hasil pembelajarannya saja dan tidak menilai proses yang dilakukan siswa sehingga dalam penyelesaian masalah tidak dituntut untuk baik karena yang di nilai adalah hasil belajar saja. Meskipun dalam pembelajaran dengan implementasi asesmen konvensional digunakan dilengkapi atau didukung dengan penggunaan media, penekanannya tetap pada proses penerimaan pengetahuan (materi pelajaran) tidak diperhatikan oleh guru sehingga banyak siswa yang berrfikir yang penting mengerti saja. Dalam hal tersebut 
kemampuan literasi sains siswa tidak dapat ditingkatkan dan dikembangkan melalui pembelajaran yang menekankan pada penerimaan pengetahuan saja, tetapi juga dilihat dari proses dan cara berpikir siswa dalam memecahkan masalah pada proses pembelajaran yang sedang berlangsung.

Uji hipotesis ketiga dilakukan dengan uji $\mathrm{F}$ melalui MANOVA menunjukkan bahwa nilai signifikansi uji Manova melalui Pillai trace, Wilks' Lambda Hotelling's trace, dan Roy's largest Root adalah < 0,001 dan nilai ini lebih kecil dari 0,05 (sig. < 0,05). Jadi hipotesis nol yang menyatakan bahwa tidak terdapat perbedaan karakter dan literasi sains siswa secara simultan antara siswa yang mengikuti pembelajaran dengan implementasi asesmen projek dengan siswa yang mengikuti pembelajaran dengan implementasi asesmen konvensional, ditolak dan hipotesis alternatif, diterima. Dengan demikian, dapat ditarik kesimpulan bahwa terdapat perbedaan karakter dan literasi sains siswa secara simultan antara siswa yang mengikuti pembelajaran dengan implementasi asesmen projek dengan siswa yang mengikuti pembelajaran dengan implementasi asesmen konvensional.

Berdasarkan hasil penelitian menunjukkan bahwa terdapat hubungan positif antara literasi sains dengan karakter siswa, dengan kekuatan korelasi yang dikategorikan yaitu sebesar 0,238. Hubungan positif ini dapat diartikan bahwa semakin tinggi kemampuan literasi sains siswa, maka semakin tinggi nilai karakter siswa. Hasil penelitian ini juga sejalan dengan penelitian yang dilakukan oleh Nilalohita (2017) yang berjudul Budaya Literasi dalam Pembentukan Karakter Siswa. Dalam hasil penelitian menyatakan terdapat hubungan positif antara kemampuan literasi secara simultan dengan kemampuan karakter pada siswa.

Dengan demikian pada dasarnya literasi sains adalah kemampuan menggunakan pengetahuan sains, mengidentifikasi pertanyaan, dan menarik kesimpulan berdasarkan bukti-bukti, dalam rangka memahami serta membuat keputusan berkenaan dengan alam dan perubahan yang dilakukan terhadap alam melalui aktivitas manusia. Menurut Yuliati (2017) seseorang yang memiliki literasi sains adalah orang yang mampu mengaplikasikan konsep sains dalam penyelesaian masalah. Hal ini juga karakter adalah cara berpikir dan berperilaku yang menjadi ciri khas tiap individu untuk hidup bekerja sama, baik dalam lingkungan keluarga, masyarakat, bangsa dan negara. Individu yang berkarakter baik adalah individu yang bisa membuat keputusan dan siap mempertanggungjawabkan tiap akibat dari keputusan yang ia buat (Suyanto, dalam Suradi: 2017). Dalam hal tersebut bisa kita lihat bahwa adanya korelasi langsung antara kemampuan karakter dan literasi sains. Artinya bahwa semakin tinggi kemampuan literasi sains, maka akan semakin baik pula karakter siswa. Dalam hal ini juga proses pembelajaran dipersiapkan dengan matang sehingga akan lebih efektif dan efisien yang tentunya akan berpengaruh pada kemampuan karakter dan literasi sains siswa. Pendidik juga memiliki peranan penting untuk menfasilitasi, membimbing dan membangkitkan kemampuan berpikir siswa dan keaktifan siswa dalam kelas. Pembelajaran dengan implementasi asesmen projek mampu memenuhi apa yang dibutuhkan siswa selama pendidik selalu berupaya untuk merancang pembelajaran yang bermakna agar dapat meningkatkan kemampuan karakter dan literasi sains siswa.

\section{SIMPULAN DAN SARAN}

Berdasarkan hasil penelitian dan pembahasan dapat ditarik kesimpulan sebagai berikut. Pertama, menunjukkan bahwa terdapat perbedaan karakter antara siswa yang mengikuti implementasi asesmen projek dengan siswa yang mengikuti asesmen konvensional pada siswa. Kedua, menunjukkan bahwa terdapat perbedaan literasi sains antara siswa yang mengikuti implementasi asesmen projek dengan siswa yang mengikuti asesmen konvensional pada siswa. Ketiga, menunjukkan bahwa terdapat perbedaan karakter dan literasi sains secara simultan antara siswa yang mengikuti implementasi asesmen projek dengan siswa yang mengikuti asesmen konvensional pada siswa. Hasil penelitian ini disarankan kepada para guru yang diharapkan dapat memberikan penilaian (asesmen) pembelajaran yang bervariasi dalam proses belajar mengajar di kelas salah satunya dengan asesmen projek, sehingga tercipta suasana pembelajaran yang menarik dan membangkitkan semangat belajar agar dapat meningkatkan hasil belajar siswa. Guru diharapkan lebih berperan aktif dalam membantu siswa dalam mengatasi kesulitan dan mengembangkan kemapuan karakter dan literasi sains siswa serta menciptakan suasa belajar yang nyaman bagi siswa. Guru diharapkan lebih mempersiapkan perencanaan pembelajaran dan menambah wawasan tentang penerapan asesmen projek dalam pembelajaran.

Berdasarkan hasil temuan dalam penelitian ini menunjukkan bahwa penerapan pembelajaran dengan implementasi asesmen projek dapat dijadikan sebagai acauan bagi pengembang penelitian berikutnya. Dengan demikian, hasil penelitian ini disarankan dapat dijadikan sebagai kajian empiris melalui pengembangan penelitian lanjutan mengenai asesmen pembelajaran secara lebih luas dan mendalam agar dapat membawa konstribusi positif dan menjadi acuan dalam pengembangan ilmu pengetahuan. Selain itu, hasil penelitian ini disarankan untuk dijadikan sebagai suatu pedoman dalam memilih model pembelajaran dalam upaya meningkatkan karakter dan literasi sains siswa sehingga hal tersebut dapat bermanfaat bagi guru maupun siswa. 


\section{DAFTAR RUJUKAN}

[1] Agustini, E. 2014. Peran Asesmen dalam Pembelajaran. Tersedia di http://niluhputuekaagustini.blogspot.com/2014/01/peran-asesmen-dalam-pembelajaran.html. Diakses pada tanggal 2 Juli 2018.

[2] Akbar, U.A.Q, dkk. 2016. "Dampak Asesmen Portofolio terhadap Pemahaman Konsep dan Sikap Siswa Sekolah Menengah Pertama pada Materi Gaya dan Gerak". Prosiding Seminar Nasional Pendidikan Sains (SNPS) 2016. Surakarta.

[3] Alfian, A., Aminah, N. S., \& Sarwanto. 2015. "Authentic Assessment Berbasis Scientific Approach sebagai Implementasi Kurikulum 2013 Di SMP Kelas VII pada Materi Suhu dan Perubahannya". Jurnal Inkuiri. Volume 4, Nomor 3.

[4] Astuti, O. W. dkk. 2017. "Pengembangan Instrumen Asesmen Berbasis Literasi Sains pada Mata Pelajaran IPA Kelas VIII Semester II". Journal Biosains, Volume 1, Nomor 2, Tahun 2017.

[5] Jazari, M. 2018. Pendidikan Karakter, Antara Harapan dan Kenyataan. Tersedia di https://www.sman1karanggede.sch.id/2018/02/08/pendidikan-karakter-antara-harapan-dan-kenyataan/. Diakses pada tanggal 2 Juli 2018.

[6] Kunandar. 2015. Penilaian Autentik (Penilaian Hasil Belajar Peserta Didik Berdasarkan Kurikulum 2013). Jakarta: PT RajaGrafindo Persada.

[7] Marhaeni, A.A.I.N, dkk. 2017. Assesmen Autentik dalam Pembelajaran Bahasa Inggris. Depok: PT Rajagrafindo Persada.

[8] Maunah, B. 2015. "Implementasi Pendidikan Karakter dalam Pembentukan Kepribadian Holistik Siswa". Jurnal Pendidikan Karakter, Tahun V, Nomor 1, April 2015

[9] Muchtar, H. 2010. "Penerapan Penilaian Autentik dalam Upaya Peningkatan Mutu Pendidikan”. Jurnal Pendidikan Penabur, No.14, Tahun ke-9, Juni 2010.

[10] Nilalohita, C.S. 2017. Budaya Literasi dalam Pembentukan Karakter Siswa. Jakarta: UIN Syarif Hidayatullah Jakarta.

[11] OECD. 2016. PISA 2015:Assessment and Analytical FrameworkScience, Reading, MathematicAnd Financial Literacy. Paris: OECD.

[12] Pantiwati, Y. 2013. Hakekat Asesmen Autentik dan Penerapannya dalam Pembelajaran Biologi. Jurnal Edukasi Matematika dan Sains. Vol. 1, No.1.

[13] Putri, D. N.. 2018. Literasi Membentuk Karakter Bangsa yang Bermoral dan Berkreativitas Tinggi. Tersedia di http://www.literasikalbar.com/2018/01/literasi-membentuk-karakter-bangsa-bermoral.html. Diakses pada tanggal 2 Juli 2018.

[14] Republika. 2018. Literasi Indonesia Sangat Rendah. Tersedia di https://www.republika.co.id/amp_version/ngm3g840. Diakses pada tanggal 2 Juli 2018.

[15] Sari, D.N.A., dkk. 2017. "Pengaruh Pembelajaran Berbasis Proyek terhadap Kemampuan Literasi Sains Siswa". Pancasakti Science Education Journal. Vol.2, No.2.

[16] Solikhin, R. 2014. Assesmen Pembelajaran. Tersedia di http://riyadsangpetualang.blogspot.com/2014/01/assesmen-pembelajaran.html. Diakses pada tanggal 2 Juli 2018.

[17] Subanji. 2017. Menumbuhkan Karakter Siswa melalui Pembelajaran Matematika Kreatif. Makalah. Disajikan dalam Seminar Nasional "Matematika dan Pendidikan Matematika" Tanggal 18 November 2017 di Solo.

[18] Suradi. 2017. Pembentukan Karakter Siswa melalui Penerapan Disiplin Tata Tertib Sekolah. BRILIANT: Jurnal Riset dan Konseptual, Volume 2, Nomor 4.

[19] Wulandari, N. \& Sholihin, H. 2015. Penerapan Model Problem Based Learning (PBL) Pada Pembelajaran IPA Terpadu Untuk Meningkatkan Aspek Sikap Literasi Sains Siswa SMP. Prosiding Simposium Nasional Inovasi dan Pembelajaran Sains 2015, Vol. 8, No.0.

[20] Yuliati, Y. 2017. Literasi Sains Dalam Pembelajaran IPA. .Jurnal Cakrawala Pendas. Vol. 3, No.2 
Rifqi, A. B. (2021)

Jurnal Pendidikan Dasar Flobamorata. Vol.2 (1) hal. 96-102. 